\title{
PASJA CHORAŁOWA ZE ZBIORU KAZAŃ KANONIKÓW REGULARNYCH KONGREGACJI LATERAŃSKIEJ W KRAŚNIKU
}

\begin{abstract}
Studia nad pasją chorałową w Polsce zainicjował - biorąc za podstawę badań zarówno średniowieczne źródła rękopiśmienne, jak i późniejsze drukowane Włodzimierz Poźniak. Jego badania uwieńczone zostały publikacją „Pasja chorałowa w Polsce” w czasopiśmie Nasza Przesztość w 1947 r. ${ }^{\text {I }}$ która stała się podstawą jego habilitacji. Ponad trzydzieści lat później problem śpiewu pasyjnego podją Antoni Reginek $^{2}$, poszerzając dotychczasową grupę źródeł o kolejne księgi rękopiśmienne pochodzące z XV i XVI w. ${ }^{3}$. Od tej pory, to jest od przeszło trzydziestu lat, nie ukazała się żadna istotna publikacja poświęcona zagadnieniu pasji monodycznej w źródłach polskich ${ }^{4}$.
\end{abstract}

I Badania Poźniaka objęły trzy księgi rękopiśmienne z XV w. (PL-Kk 58, PL-Kk 59, PL-Kp I706) oraz pięć ksiąg drukowanych z XVI-XVIII w., zob.: Włodzimierz Poźniak, „Pasja chorałowa w Polsce”, Nasza Przesztość: Studia do Dziejów Kościota i Kultury Katolickiej w Polsce 3 (I947), s. 37-9I.

2 Praca licencjacka tego autora pt. „Pasje chorałowe w polskich zabytkach XV i XVI wieku” powstała w Instytucie Muzykologii Kościelnej Katolickiego Uniwersytetu Lubelskiego pod kierunkiem ks. prof. Karola Mrowca w I980 roku. Na jej podstawie ukazały się trzy publikacje: Antoni Reginek, „Śpiewy pasji chorałowej w Polsce w XV i XVI wieku”, w: Musica Medii Aevi, red. Jerzy Morawski, t. 7, Kraków I986, s. 55-II6, a także tegoż: „Pasja chorałowa w odnowionej liturgii. Propozycje śpiewów na podstawie najstarszych polskich rękopisów pasyjnych”, Ślaskie Studia Historyczno-Teologiczne I4 (I98I), s. 26I-298, oraz: „Pasja. Dzieło muzyczne”, w: Encyklopedia katolicka, red. Edward Gigilewicz, t. I4, Lublin 20Io, szp. I433-37.

3 Podstawę źródłową studiów Reginka stanowią następujące rękopisy: PL-Kk 235, PL-Kk 240, PL-Kc 3606, PL-Kc 3607, PL-Kc 36I3, PL-WRk 58, PL-WRk i78, PL-WRu I Q 225. Autor wskazuje na istnienie dwóch odmiennych tradycji: diecezjalnej, prezentowanej przez źródła wawelskie, rękopisy ze Środy Śląskiej i Żagania, oraz zakonnej, przekazanej przez księgi bernardyńskie. Wyróżnienie dwóch odrębnych tradycji na podstawie tak nielicznej prezentacji źródeł zakonnych i to pochodzących z jednego klasztoru (tylko trzy księgi bernardyńskie) nie wydaje się jednak uzasadnione, por.: A. Reginek, „Śpiewy pasji”, op. cit., s. 93.

4 Publikacje polskich autorów w większym lub mniejszym stopniu odnoszące się do pasji chorałowej zasadniczo opierają się na dotychczasowych wynikach badań Poźniaka bądź Reginka (op. cit.), por.: Hieronim Feicht, „Muzyka liturgiczna w polskim średniowieczu”, w: Musica Medii Aevi, red. Jerzy Morawski, t. I, Kraków I965, s. 9-52; Katarzyna Morawska, Średniowiecze. Częś́́ 2: 1320-I500, Warszawa 1998 (= Historia muzyki polskiej I); Janusz Drewniak, „Muzyczna forma dramatyzacji motywu cierpienia Chrystusa”, Liturgia Sacra I5 (2009) nr I, s. II5-I2I; tegoż, „Motyw cierpienia Chrystusa w Pasji Johanna Sebastiana Bacha”, Studia Wroctawskie I8 (2016), s. 317-338. 
Do lat osiemdziesiątych za najstarsze źródło pasyjne powszechnie uznawano, za publikacją Poźniaka, tzw. kancjonał Gosławskiego z I489 r. ${ }^{5}$, występujący w literaturze przedmiotu pod nazwą Cantionale cum Agenda oraz Passionale (PL-Kk 58). Dalsze poszukiwania przesunęły datę najstarszego zapisu muzycznego pasji o kilkadziesiąt lat wstecz. Antoni Reginek wskazał na kolejne zabytki starsze od wspomnianego kancjonału, spośród których Cantionale z Wieliczki (PL-Kk 240), datowane na 1. I447-567 i przechowywane w Archiwum Kapitulnym na Wawelu, uznane zostało za najdawniejsze polskie źródło pasji chorałowej. Jednakże już w grupie źródeł objętych badaniami Poźniaka i Reginka daje się wyodrębnić kodeks starszy od rękopisu z Wieliczki. Jest to kancjonał z katedry wawelskiej PL-Kk 59. Pierwszy z autorów (Włodzimierz Poźniak) - prawdopodobnie opierając się na danych z katalogu rękopisów wawelskich Ignacego Polkowskiego ${ }^{8}$ - błędnie uznał pasje z tego kancjonału za kompozycje szesnastowieczne9. Datowanie to zostało zweryfikowane przez Barbarę Miodońską (1967), która wskazała na lata trzydzieste XV w. jako czas powstania księ$\mathrm{gi}^{\mathrm{IO}}$, co potwierdzają także badania paleograficzne notacji muzycznej zawartej w tym rękopisie ${ }^{\text {II. }}$ Tym samym czas powstania najstarszej pasji chorałowej został przesunięty mniej więcej o kolejne dziesięciolecie. Reginek z kolei podaje zweryfikowaną już datację kancjonału PL-Kk 59 $9^{\mathrm{I2}}$, jednak - być może ze względu na pomocniczy charakter tego źródła w jego pracy - autorowi umknął rzeczywisty porządek chronologiczny badanych ksiąg, wskutek czego kancjonał ten nie został przez niego uwzględniony przy ustalaniu najstarszych zabytków pasji chorałowej ${ }^{13}$.

5 Por.: W. Poźniak, op. cit., s. 89-9o; H. Feicht, op. cit., s. 27; A. Reginek, „Śpiewy pasji”, op. cit., s. 92.

6 Rękopis PL-Kk 58 ze względu na jego różnorodną zawartość był także przedmiotem zainteresowań wielu innych badaczy, zob.: Maria Szczepańska, „Do historii muzyki wielogłosowej w Polsce z końca XV w.”, Kwartalnik Muzyczny 2 (1930) nr 8, s. 277-281; Iwona Babioch, „Liber generationis w polskich źródłach średniowiecznych”, Muzyka 33 (I988) nr I, s. 3-30; Paweł Gancarczyk, „Cantus planus multiplex. Polifonia chorałowa w Polsce XIII-XVI wieku”, w: Notae musicae artis. Notacja muzyczna w źródtach polskich XI-XVI wieku, red. Elżbieta Witkowska-Zaremba, Kraków 1999, s. 349-40I; Jakub Kubieniec, „Lamentacje chorałowe w krakowskich rękopisach liturgicznych od XII do XVIII wieku”, Muzyka 44 (1999) nr I, s. 7-45; Anita Pyrek-Nąckiewicz, „Lamentacje Jeremiasza z Passionale (akkk 58, I489) z Archiwum Krakowskiej Kapituły Katedralnej na Wawelu”, Pro Musica Sacra I4 (2016), s. 213-240.

7 A. Reginek, „Śpiewy pasji”, op. cit., s. 6o; por. także: Wojciech Danielski, „Agendy i kancjonały katedry krakowskiej na Wawelu", Roczniki Teologiczno-Kanoniczne I4 (1977) nr 4, s. 48-49.

8 Ignacy Polkowski, Katalog rękopisów kapitulnych katedry krakowskiej, Kraków I884, s. 52.

9 W. Poźniak, op. cit., s. 44.

Io Barbara Miodońska, Iluminacje krakowskich rękopisów z pierwszej potowy XV wieku w Archiwum Kapituty Metropolitalnej na Wawelu, Kraków I967, s. I44.

II Adam Sutkowski, „Cechy paleograficzne notacji muzycznych w polskich rękopisach średniowiecznych”, w: Musica Medii Aevi, red. Jerzy Morawski, t. I, Kraków 1965, s. 65-66 (tamże reprodukcja pierwszej karty rękopisu, il. I5).

I2 A. Reginek w opisach badanych przez siebie ksiąg zasadniczo opiera się na publikacji ks. Wojciecha Danielskiego (op. cit.), który w przypadku kancjonału PL-Kk 59 (zob. s. 45) stosuje zweryfikowaną datację za Miodońską (op. cit.).

I3 Zob.: A. Reginek, „Śpiewy pasji”, op. cit., s. 63 (opis rękopisu PL-Kk 59), 92 (wnioski). 
Pasje chorałowe przedstawione w pracach Włodzimierza Poźniaka oraz Antoniego Reginka nie zamykają jednak listy tego rodzaju kompozycji ${ }^{14}$. Kolejne źródło pasji monodycznej przywołuje w swojej publikacji przy okazji omawiania źródeł polifonii chorałowej Paweł Gancarczyk (2000) ${ }^{\text {I5 }}$. Przechowywany w zbiorach Zakładu Narodowego im. Ossolińskich we Wrocławiu kancjonał PL-WRzno 3070/II, według ustaleń autora pochodzący z l. I450-70 z Małopolski, zawiera wszystkie cztery pasje ${ }^{\mathrm{I} 6}$. W toku prac dokumentacyjnych Instytutu Sztuki PAN podczas kwerendy w Bibliotece Wyższego Seminarium Duchownego im. Księży Chodyńskich we Włocławku na światło dzienne wydobyto szesnastowieczny rękopis (PL-WŁs 720) także zawierający pasje chorałowe. Dzięki dalszym kwerendom i badaniom liczba kompozycji może jeszcze znacznie wzrosnaćc $c^{17}$. Celem niniejszego artykułu jest zaprezentowanie nieznanej dotychczas kompozycji pochodzącej z rękopisu przechowywanego w Bibliotece Metropolitalnego Seminarium Duchownego w Lublinie pod sygnaturą "Rkps I4” (PL-Ls I4; dawne sygnatury: 235, B I3, B I7 ${ }^{\mathrm{I} 8}$, która wydaje się obecnie najstarszą kompozycją pochodzącą z polskiego źródła' ${ }^{19}$.

Wzmiankę o tym kodeksie znaleźć można u Katarzyny Morawskiej²0, która wymienia go na liście najstarszych źródeł pasji chorałowej w Polsce ${ }^{21}$ (jest to jedyny rę-

I4 Studia Reginka poza źródłami małopolskimi obejmują także księgi śląskie, które autor, nie podając uzasadnienia, zalicza do zabytków polskich.

I5 Paweł Gancarczyk, „Nieznane źródła polifonii chorałowej w Polsce XV wieku”, Muzyka 45 (200o) nr 2, s. $89-106$.

I6 Fol. Ir-9r: pasja według św. Mateusza; fol. 9r-I5v: pasja według św. Marka; fol. I5v-22v: pasja według św. Łukasza; fol. 22v-26v: pasja według św. Jana; zob. ibid., s. 98-99.

I7 Zamierzeniem autorki niniejszego artykułu jest zebranie szerszego zasobu polskich średniowiecznych rękopiśmiennych źródeł pasji chorałowej i szczegółowe opracowanie tematu.

I8 Za zwrócenie uwagi na źródło PL-Ls I4 chciałabym podziękować prof. Elżbiecie Witkowskiej-Zarembie. Opis rękopisu PL-Ls I4 i jego zawartości znajduje się w: Henryk Damian Wojtyska, „Katalog rękopisów Biblioteki Seminarium Duchownego w Lublinie”, Archiwa, Biblioteki i Muzea Kościelne 28 (I974), s. 232-233. Katalogowy opis rękopisu: łac., I poł. XV w., papier, $29 \times 2$ I, $5 \mathrm{~cm}$ i mniej, k. I97, kol. 2, opr. sk. wsp.

I9 W zbiorach polskich zachował się również jedenastowieczny rękopis zawierający szczątkowy zapis muzyczny (cheironomiczny) nad ostatnimi słowami Chrystusa - „Eli, Eli lama sabachtani” - z pasji św. Mateusza. Kodeks ten nie jest uwzględniany w chronologicznym zestawieniu najstarszych pasji zawartych w źródłach polskich ze względu na jego obce pochodzenie - jest to francuski ewangeliarz (najprawdopodobniej powstał w jednym z klasztorów na granicy pomiędzy północną Francją a południową Flandria) przechowywany w Bibliotece Narodowej (PL-Wn 33II). Występują tu litterae significativae („t” dla Chrystusa, „c” dla narratora oraz „s” dla turby). Ewangeliarz PL-Wn 33 II dokumentuje jeden z wcześniejszych zapisów muzycznych pasji, pochodzący sprzed czasu ukształtowania się tonu pasyjnego jako odrębnego gatunku muzyczno-liturgicznego, zob.: Nino Albarosa, „Notacja bezliniowa w polskich źródłach chorałowych XI-XIII w.”, w: Notae musicae artis, op. cit., s. I54-I55 (na s. I54 reprodukcja karty ewangeliarza PL-Wn 33II z zapisem neumatycznym); por. także: Stanisława Sawicka, „Les principaux manuscrits à peintures de la Bibliothèque Nationale de Varsovie, du Château Royal et des Bibliothèques: des Zamoyski à Varsovie, du Seminaire de Płock et du Chapitre de Gniezno”, Bulletin de la Société Française de Reproductions de Manuscrits à Peintures I9 (1938), s. I4-22.

20 Por. K. Morawska, op. cit., s. 320.

2I Podobnie jak Reginek, autorka zalicza rękopisy śląskie do źródeł polskich. Na liście rękopisów znajduje się także pasjonał (?) z kolegiaty wiślickiej, który miał tam znajdować się w I483 r., a obecnie uznawany jest za zaginiony; por. K. Morawska, op. cit., s. 320. 
kopis z tej listy, który nie został objęty wcześniejszymi badaniami). Autorka pierwsze miejsce przyznaje wspomnianemu już kancjonałowi wawelskiemu z lat trzydziestych XV w. (PL-Kk 59), podczas gdy kodeks lubelski z nieznaną dotychczas kompozycją wymienia na miejscu trzecim, nie podając przy tym jego datacji ${ }^{22}$. Jak wynika jednak z notki w PL-Ls I4, umieszczonej obok ostatniego systemu notacyjnego kompozycji na fol. I72v, zapis muzyczny pasji sporządzono w I4II r., a więc przed PL-Kk 59 (,[...] finis adest operis, posco incedere [?] laboris. Sub anno domini MCCCCXI etc. Habetur finis huius operis"). Zgodnie z siedemnastowiecznym wpisem ${ }^{23}$ zamieszczonym na pierwszej karcie tegoż kodeksu miał on być własnością kanoników regularnych kongregacji laterańskiej w Kraśniku (fol. Ir: „Conventus Crasnicensis Canonicorum Regularium Lateranensium") ${ }^{24}$. Kanonicy regularni sprowadzeni zostali do Kraśnika w II poł. XV w., kiedy to Jan Rabsztyński h. Topór (zm. przed I3 V I499 r.) ufundował tam w 1. I468-69 klasztor ${ }^{25}$ będący jedną z pierwszych filii działającego od I405 r. konwentu kanoników regularnych podkrakowskiego Kazimierza ${ }^{26}$. Zapis pasji w PL-Ls I4 powstał zatem zanim jeszcze kanonicy regularni osiedlili się w Kraśniku. Ponieważ założenie wspólnoty krakowskiej nastąpiło na kilka lat przed powstaniem księgi, a dom zakonny w Kraśniku należał do jednej z pierwszych filii, można by przypuszczać, iż rękopis dotarł na ziemię lubelską z krakowskiego Kazimierza, być może już z pierwszymi zakonnikami i prepozytem Janem z Bytomia (zm. I507) na czele ${ }^{27}$. Jak wszystkie znane dotąd pasje zawarte w źródłach polskich, tak i kompozycja z PL-Ls I4 pochodziłaby zatem z Małopolski.

Będący w chwili obecnej najstarszym polskim źródłem pasji chorałowej kodeks kraśnicki jest księgą niemuzyczną, a mianowicie zbiorem kazań (sermones), obejmującym m.in. Linea salutis autorstwa Hieronima z Pragi (fol. Ir-85r ${ }^{28}$ oraz Sermones de sanctis Peregryna z Opola (fol. 85r-136r) ${ }^{29}$. W części oryginalnej rękopisu znalazła się także pasja według św. Mateusza ${ }^{30} \mathrm{z}$ notacją muzyczną (fol. I65r-I72v;

22 Datacja według opisu katalogowego to I poł. XV w.; H.D. Wojtyska, op. cit., s. 232-233.

23 Por. ibid., s. 228.

24 Wszystkie polskie prepozytury od XVI w. wchodziły w skład kongregacji laterańskiej.

25 Klasztor istniał prawie czterysta lat - do jego kasaty w I864 r.; Ewa Zielińska, „Nekrolog klasztoru kanoników regularnych św. Augustyna w Kraśniku”, Rocznik Lubelskiego Towarzystwa Genealogicznego (2010) nr 2, s. 79-I25.

26 W I405 r. Władysław Jagiełło sprowadził z Kłodzka do kościoła Bożego Ciała w Krakowie kanoników regularnych, gdzie od razu rozpoczęła swoją działalność grupa skryptorów, zob.: K. Morawska, op. cit., s. 92.

27 Por.: E. Zielińska, op. cit.

28 Hieronim z Pragi, ur. w II poł. XIV w. w Pradze, zm. w I440 r. w Wenecji. W 1. I405-Io (podczas pobytu w Polsce) ułożył m.in. zbiór kazań Linea salutis aeternae; przed I4I3 r. wyjechał do Włoch, gdzie został kamedułą; H.D. Wojtyska, op. cit., s. 232-233.

29 Peregryn z Opola OP, ur. przed I260 r., zm. po 1335 r., przełożony dominikanów w Raciborzu i Wrocławiu, prowincjał polsko-śląskiej prowincji w 1. I318-27; jego Sermones de tempore et de sanctis, napisane w między I297 a I304 r., były bardzo rozpowszechnione w średniowieczu; H.D. Wojtyska, op. cit., s. 232, przyp. I7.

30 Odczytywanie Mateuszowego opisu Męki Pańskiej należy do najdawniejszej praktyki proklamacji pasji ewangelicznej i przynajmniej od IV w. związane jest z liturgią Niedzieli Palmowej. Najstarsze świadectwo 
rękopis obejmuje I97 kart), która jest zarazem jedyną kompozycją muzyczną w tej księdze ${ }^{31}$. Jest to szczególny przypadek, gdy pasja chorałowa pojawia się w odosobnieniu, a nie w grupie czterech pasji, jak to ma miejsce w pozostałych rękopisach polskich, a zarazem jedyny przypadek pasji zapisanej w takim, niemuzycznym kontekście. Trudno odpowiedzieć na pytanie dlaczego pasja, i to z zapisem muzycznym, znalazła się wśród kazań - i to jako część oryginalna księgi, a nie późniejszy dopisek - tym bardziej iż są to kazania przeznaczone na różne okoliczności, niezwiązane z okresem pasyjnym.

Pasja z rękopisu PL-Ls I4 została zapisana systemem neum mieszanych metzeńsko-gotyckich ${ }^{32}$ na czterech lub pięciu liniach (najwyższa pełni jednocześnie rolę linii tekstu) z zastosowaniem kluczy $c$ i $F$, bez użycia kustoszy (z rzadka pojawia się klucz $g$ dopisany w późniejszym czasie). W zapisie tej kompozycji nie występują litery oznaczające (tzw. litterae significativae) ${ }^{33}$. Rękopis kraśnicki nie zawiera też ewangelii

mówiące o liturgicznej proklamacji pasji stanowi opis liturgii Wielkiego Tygodnia w Jerozolimie według Egerii (Aeterii). Wzmianki o pasjach znajdują się także u św. Augustyna (Św. Augustyn z Hippony, Sermones, 232,2.), por.: Kurt von Fischer, „Passion”, w: The New Grove dictionary of music and musicians, red. Stanley Sadie, London 200I, t. 19, s. 200; Władysław Szołdrski, „Peregrynacja (Aeterii?) do miejsc świętych z końca IV w.”, Homo Dei 33 (1964), s. 43-45; Kurt von Fischer, „Die Passion von ihren Anfängen bis ins 16. Jahrhundert", w: Gattungen der Musik in Einzeldarstellungen: Gedenkschrift Leo Schrade, red. Wulf Arlt, Bern 1973, s. 576. Stopniowo ustala się miejsce pozostałych pasji w liturgii: według św. Jana w Wielki Piątek, według św. Łukasza w Wielką Środę, a najpóźniej według św. Marka - w Wielki Wtorek (prawdopodobnie dopiero w X w.); K. von Fischer, „Passion”, op. cit., s. 200; Waldemar Pałęcki, „Pasja. W liturgii", w: Encyklopedia Katolicka, red. Edward Gigilewicz, t. I4, Lublin 20ı, szp. I432-33.

3I Na wyklejkach i desce znajdują się wpisy powstałe w czasie późniejszym pochodzące od trzech różnych rąk: wpisy tekstów błogosławieństwa wody, paschału, chleba i jaj (przednia wyklejka) oraz pieśn „Zdrova bodz Krolevno" bez notacji muzycznej (tylna wyklejka); na drugiej desce okładki wpisana jest także notatka łacińska o dziesięcinach, H.D. Wojtyska, op. cit., s. 233.

32 Terminologia za: Janka Szendrei, „Notacja liniowa w polskich źródłach chorałowych XII-XVI wieku”, w: Notae musicae artis, op. cit., s. 187-28I.

33 Od XIV w. upowszechnia się stosowanie oznaczeń literowych - tzw. litterae significativae - dla określenia poszczególnych ról, jak na przykład „c" (cronista lub cantor) dla partii ewangelisty, „s” (synagoga) dla partii turby obejmującej wypowiedzi ludu (tłumu oraz pojedynczych osób, np. Piotra, Judasza, Kajfasza itd.) oraz litera "t” dla oznaczenia partii Chrystusa, która z czasem zostaje zastąpiona krzyżykiem (†). Pierwotnie jednak litterae significativae (pojawiające się w rękopisach już od końca VIII w.) nie określały podziału ról, lecz wskazywały na zróżnicowanie rejestrów tonów recytacyjnych bądź tempa, a czasem nawet na zmiany agogiczne odróżniające od siebie wypowiedzi poszczególnych osób - narratora, Chrystusa i pozostałych; np. „c" - celeriter lub cito (szybko, płynnie) przed słowami narratora; „t” tenere, trahere, tarde (wolniej, ciągnąc, rozwlekle) przed słowami Chrystusa; oraz „s” - sursum, superius (żwawiej, wyżej, w wyższym rejestrze) przed wypowiedziami pozostałych osób (w różnych regionach stosowano odmienne litery oznaczające, które dawały zasadniczo podobne wskazówki interpretacyjne), por.: Michel Huglo, „L'absence de lettres significatives notkériennes dans l'école de Metz au IXe siècle", w: L'art du chantre carolingien. Découvrir l'esthétique première du chant grégorien, red. Christian-Jacques Demollière, Metz 2004, s. 67-79; Gionata Brusa, „Litterae passionis extra passionem». La testimonianza del codice Berlin, Staatsbibliothek Preussischer Kulturbesitz, Lat. Fol. 920", Rivista internazionale di musica sacra 32 (20II) nr I-2, s. 25I-253; Michel Huglo, Barbara Haggh-Huglo, „Des lettres de la passion aux lettres significatives Notkériennes”, w: „Quod ore cantas corde credas”. Studi in onore di Giacomo Baroffio, red. Leandra Scappaticci, Vaticano 2013 (= Monumenta studia instrumenta liturgica 70$)$, s. $427-436$. 
popasyjnej ${ }^{34}$, ani wskazówki mówiącej o jej wykonywaniu w tonie ewangelijnym, przytoczony jest jedynie początek tekstu ewangelii („Altera autem die quæ est post parasceven convenerunt").

Pasja z rękopisu PL-Ls I4 oparta jest na tonie pasyjnym F35, stosowanym we wszystkich znanych pasjach zawartych w źródłach polskich; ton ów po raz pierwszy pojawia się i od XIV w. szeroko rozpowszechnia w księgach niemieckich. Ze wstępnych badań wynika, iż jest to najczęściej stosowany ton w Europie Środkowej. Zgodnie z jego strukturą recytatyw partii Chrystusa przebiega na dźwięku $f^{\prime}$, partii ewangelisty na dźwięku $c^{2}$, a turby - na $f^{2}{ }^{36}$. Ponadto w melodii pasyjnej PL-Ls I4 występuje dodatkowy element strukturalny w postaci drugiego dźwięku recytatywnego w partii turby $-d^{2}$.

Posłużenie się tym samym tonem w poszczególnych pasjach nie oznacza bynajmniej identycznego rozwiązania melicznego formuł typowych dla tych kompozycji. Poniżej przedstawione zostaną poszczególne zwroty melodyczne - formuły typowe ${ }^{37}$ wraz z ich modyfikacjami występujące w pasji PL-Ls I4 oraz melodia Eli, charakteryzująca się własnym, bardziej wyrafinowanym opracowaniem muzycznym ${ }^{38}$.

\section{PARTIA EWANGELISTY}

Zakres melodyczny partii ewangelisty mieści się w ambitusie czystej kwinty: $f^{I}-c^{2}$, którego górną granicę wyznacza dźwięk odpowiadający tenorowi tejże partii $\left(c^{2}\right)^{39}$.

$34 \mathrm{Z}$ pasją ściśle łączy się ewangelia popasyjna, zamykająca proklamację opisu Męki Pańskiej (następuje po terminatio narratora). Melodie ewangelii popasyjnej występują zarówno w formie ozdobnej, jak i zdecydowanie recytatywnej; nierzadko ewangelie zapisywane są także bez notacji muzycznej i są wykonywane w zwyczajnym tonie ewangelijnym, wówczas może pojawić się uwaga „cantatur in tono Evangelii”, por. W. Poźniak, op. cit., s. 42; A. Reginek, „Śpiewy pasji”, op. cit., s. 66.

35 Melodie o takiej strukturze Kornél Bárdos określa jako „Dur Typus”, zob. Kornél Bárdos, Volksmusikartige Variierungstechnik in den ungarischen Passionen (I5. bis I8. Jahrhundert), Budapest 1975, s. 65. Ton ten stał się podstawą edycji watykańskiej; por. K. von Fischer, „Passion”, op. cit., s. 202; por. także: Theodor Göllner, „Unknown passion tone in sixteenth-century Hispanic sources”, Journal of the American Musicological Society 28 (1975) nr I, s. 46-7I.

36 Podział pasji ewangelicznej na poszczególne role oraz ich powiązanie z odmiennymi rejestrami kantylacji stało się istotnym elementem charakterystycznym tego gatunku muzyczno-liturgicznego (pasji chorałowej) odróżniającym go od lekcji i ewangelii.

37 Są to stałe zwroty melodyczne ściśle związane ze strukturą tekstu.

38 W edycji watykańskiej ostatnie słowa Jezusa („Eli...”) nie mają własnego, odrębnego opracowania muzycznego, ich struktura meliczna oparta jest na formułach typowych dla partii Chrystusa.

39 Zwroty melodyczne partii narratora - jak flexa czy metrum - charakterystyczne dla pasyjnego tonu F były stosowane już wcześniej w śpiewie lekcji i oracji, por.: Andry Bernard, „Le chant liturgique de la Passion”, Études grégoriennes 29 (200I), s. 95-127; Joseph Pothier, Les mélodies grégoriennes, Tournai I880; Jerzy Liban, Pisma o muzyce, opr. i przekł. Elżbieta Witkowska-Zaremba, Kraków 1984. 
Exordium i initium ${ }^{40}$

W rękopisie kraśnickim PL-Ls I4 zwrot melodyczny exordium jest tożsamy z formułą initium, która występuje w postaci wznoszącej się tercji małej (przykł. ıa). Jako zupełnie wyjątkowy przypadek pojawia się wariant initium z wypełnioną tercją (przykł. rb). Zdarza się nieraz, iż po zastosowaniu flexy melodia powraca na stopień recytatywu bez uprzedniego wprowadzenia formułą inicjalną.

Ia

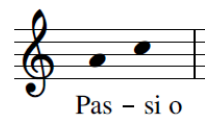

Ib

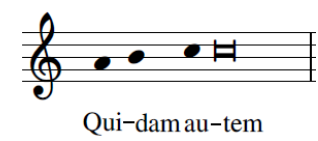

Flexa $^{4}$

Flexa występuje w postaci opadającej tercji małej ze stopnia tenorowego - w przypadku partii narratora dźwięku $c^{2}$ (przykł. 2a). Struktura meliczna podstawowego zwrotu flexy związana jest z wyrazem paroksytonicznym, zaś w przypadku akcentu proparoksytonicznego stosuje się modyfikację epénthesis ${ }^{42}$, dodając dolny dźwięk tercji (przykł. 2b). Czasem pojawia się także wariant melodyczny tej formuły, w którym na ostatniej sylabie występuje kilka dźwięków stroficznych (przykł. 2c). Podobnie jak w przypadku initium, występuje również wariant melodyczny flexy z wypełnioną tercją (przykł. 2d). W kilku miejscach użyto modyfikacji epénthesis pomimo wyrazów paroksytonicznych.

$2 a$

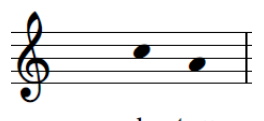

sacerdo-tum

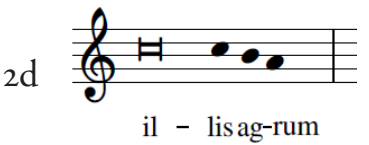

$2 \mathrm{~b}$

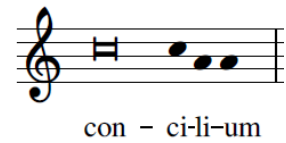

$2 \mathrm{C}$

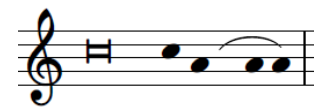

la - tro-nes

Metrum $^{43}$

Podstawową formułę melodyczną metrum stanowi zejście sekundowe ze stopnia recytacyjnego $\left(c^{2}\right)$ na dźwięk $a^{I}$, po którym następuje wznosząca się tercja prowadząca

Exordium - zwrot melodyczny rozpoczynający pasję, najczęściej jest tożsamy z formułą initium - zwrotem rozpoczynającym poszczególne frazy.

4I Zawieszenie głosu w dłuższej frazie, często występuje w miejscu przecinka.

42 Dodanie dźwięku lub grupy dźwięków w środku formuły tonicznej. W sprawie modyfikacji melodii gregoriańskich zob.: Paolo Feretti, Estetica gregoriana ossia trattato delle forme musicali del canto gregoriani, Roma 1934, s. 75-88; Dominicus Johner, Wort und Ton in Choral, Leipzig 1953, s. I5I-I56; Alberto Turco, Il canto gregoriano. Toni e modi, Roma 1996, s. 43; Rastislav Adamko, Kantylacje liturgiczne w mszale stowackim „Rimsky Misál” z I980 roku, Levoča 2005, s. 33-44.

43 Zwrot kadencyjny występujący wewnątrz frazy zwykle odpowiadający dwukropkowi, średnikowi, czasem też przecinkowi (kadencja wewnętrzna). 
melodię z powrotem na dźwięk tenorowy (przykł. 3a). Poza zasadniczym zwrotem dość często stosowany jest wariant melodyczny metrum z wypełnioną tercją wznoszącą się (przykł. 3b). W obu przypadkach $-\mathrm{z}$ wypełnieniem tercji na końcu formuły (przykł. 3b) czy bez (przykł. 3a) - akcent słowny zasadniczo związany jest z przedostatnim dźwiękiem metrum ${ }^{44}$, w związku z czym w pierwszym zwrocie melodycznym akcent przypada na dźwięk $a^{I}$, w drugim zaś na $b^{I}$.

$3 a$

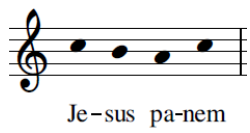

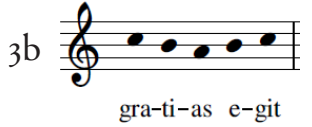

Zdarzają się także inne warianty melodyczne tej formuły będące wynikiem zastosowania modyfikacji per additionem (epénthesis, epithesi45), której użyto ze względu na proparoksytoniczny wyraz w zakończeniu formuły (przykł. 4a), sporadycznie zaś bez tego rodzaju uzasadnienia (przykł. 4b). Kilkakrotnie w metrum występują także dźwięki stroficzne (od dwóch do czterech) - głównie na ostatniej sylabie i zupełnie wyjątkowo w środku formuły. W kilku innych przypadkach zastosowano przeciwnego rodzaju modyfikację - per suspensionem (opuszczenie dźwięku lub grupy nut), opuszczając dźwięk $h^{T} \mathrm{w}$ środku formuły (syncope $)^{46}$; co więcej, niemal zawsze ta wersja melodyczna metrum związana jest ze słowem „Jesum” (przykł. 4c).

$4 \mathrm{a}$

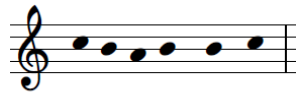

In il-lo tem-po-re

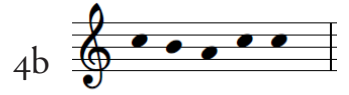

e-um cla-mi-dem
4C

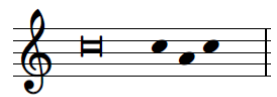

con - tra Je-sum

Wariant szczególny stanowi melodia zawieszona na dźwięku $h^{I}$, występująca jedynie trzykrotnie w całej pasji. Jest to dość typowy zabieg stosowany w przypadku imion hebrajskich, dla których charakterystyczne jest specyficzne intonowanie ostatniej sylaby (przykł. sa i 5 b) ${ }^{47}$.

5a

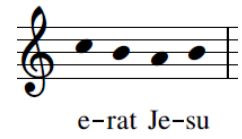

$5 \mathrm{~b}$

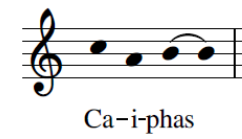

44 Poza kilkoma przypadkami, w których akcent słowny wyraźnie nie jest uwzględniony w kształtowaniu się formuły melodycznej metrum.

45 Dodanie nuty lub grupy nut na końcu formuły, zob.: P. Feretti, op. cit., s. 84 .

46 Opuszczenie dźwięków w środku formuły melodycznej, zob. ibid., s. 77.

47 Zawieszenie melodii na dźwięku $h^{I}$ przy imionach hebrajskich zdarza się także w innych pasjach polskich, zob.: Dominicus Johner, Grosse Choralschule, Regensburg 1937, s. I94; D. Johner, „Wort und Ton”, op. cit., s. 23; A. Reginek, „Śpiewy pasji”, op. cit., s. 7I. 
Punctum $^{48}$

Melodia punctum ma charakter opadający od dźwięku recytacyjnego do finalnego. Podstawowy zwrot melodyczny związany jest z wyrazem paroksytonicznym w zakończeniu formuły (przykł. 6a). Podobnie jak w poprzednich formułach melodycznych (flexa, metrum) istnieją także różne warianty punctum wynikające z zastosowania modyfikacji epénthesis w przypadku wyrazów proparoksytonicznych (przykł. 6b) ${ }^{49}$ oraz dźwięków stroficznych w zakończeniu (bistrofa, tristrofa, np.: $c^{2}-g^{I}-a^{I}-f^{I} f^{I}$ ). Trzykrotnie zdarza się podwójne zastosowanie modyfikacji epénthesis $\mathrm{w}$ ramach jednego zwrotu melodycznego (przykł. 6c).

$6 \mathrm{a}$

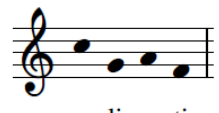

o-li-ve-ti
$6 \mathrm{~b}$

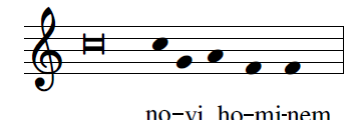

$6 c$

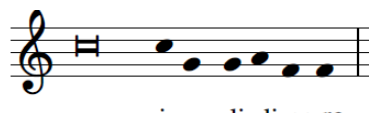

\section{Conclusio przed partią Chrystusa ${ }^{50}$}

Zwrot kadencyjny wypowiedzi ewangelisty przed partią Chrystusa jest bardziej rozbudowany melodycznie, bowiem do tej pory formuly typowe (exordium, initium, flexa, metrum, punctum) były traktowane sylabicznie, w conclusio natomiast na trzeciej sylabie od końca występuje trzyelementowa neuma climacus. Funkcją conclusio jest jednocześnie zamknięcie wypowiedzi narratora, jak i wprowadzenie w niższy rejestr właściwy dla następującej po nim partii Chrystusa:

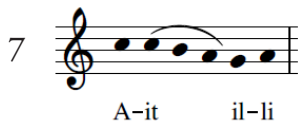

Poza jednym przypadkiem zwrot melodyczny conclusio łączy się z dwoma wyrazami paroksytonicznymi (najczęściej są to dwa wyrazy dwusylabowe). W ten sposób pierwszy i przedostatni dźwięk tej melodii odpowiadają akcentom słownym.

W większości przypadków zapisu muzycznego tego conclusio w PL-Ls I4 w późniejszym czasie dodano dźwięk $d^{2}-$ jako pierwszą nutę neumy climacus (dźwięk ten jest obecny m.in. w źródłach krakowskich). Tak jak we wszystkich pozostałych formułach melodycznych wypowiedzi ewangelisty, zdarzają się notacje dźwięków reperkusyjnych na ostatniej sylabie (tristrofa). Poza tym, z rzadka pojawiają się przypadki conclusio zakończonego dźwiękiem $f^{I}$, a nie $a^{I}$, jak to ma miejsce w większości conclusiones ewangelisty przed słowami Chrystusa.

48 Zwrot melodyczny kończący zdanie (frazę), zasadniczo jest związane z kropką.

49 Dwukrotnie zdarza się użycie tej modyfikacji pomimo paroksytonicznego wyrazu w zakończeniu formuły.

50 Formuła melodyczna związana z zakończeniem słów narratora, będąca zarazem przejściem do słów Chrystusa. 
Conclusio przed partią turby ${ }^{51}$

Podczas gdy linia melodyczna conclusio przed partią Chrystusa ma kierunek opadający, prowadząc do nieco niższego rejestru, melodia conclusio przed wypowiedzią turby wprowadza do rejestru wyższego, kończąc swój przebieg na dźwięku tenorowym. Podobnie jak w przypadku poprzedniego conclusio, trzecia sylaba od końca otrzymuje neumę trzyelementową - torculus. Akcent słowny związany jest z przedostatnim dźwiękiem formuły, a nie bardziej ozdobną neumą torculus, która zawsze przypada na sylabę pretoniczną (tak jak neuma climacus w conclusio przed partią Chrystusa).

\section{8}

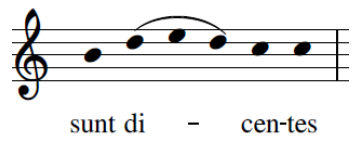

Warianty melodyczne conclusio przed turbą powstają zarówno wskutek modyfikacji per suspensionem (opuszczenie dźwięku), jak i per additionem (dodanie dźwięku). W obu przypadkach modyfikacje dotyczą początku formuly melodycznej: aphéresis ${ }^{{ }^{2}}$ - dla tekstu krótszego, oraz prósthesis ${ }^{33}$ - dla dłuższego. Także i tę formulę melodyczną zamyka nieraz grupa dźwięków stroficznych - bivirga bądź trivirga.

\section{Terminatio $^{54}$}

Terminatio, kończące nie tylko wypowiedź ewangelisty, ale i całą pasję, jest najbardziej rozbudowaną formułą melodyczną w danej partii. Melodia rozpoczyna się dźwiękiem $a^{I}$, zmierza w kierunku ascendentalnym do $e^{2}$, po czym schodzi do $h^{I}$ (zob. przykład poniżej). Pasja kończy się więc na stopniu niestabilnym $\left(h^{T}\right)$; prawdopodobnie jest to związane z przejściem do następującej po niej ewangelii popasyjnej, która w PL-Ls I4 nie została zapisana.

9

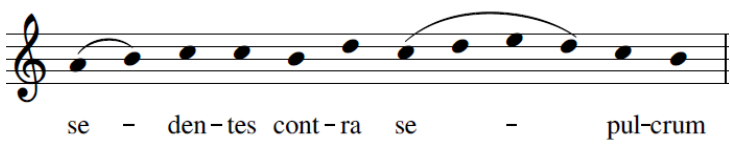

\section{PARTIA CHRYSTUSA}

Formuły typowe dla partii Chrystusa należy rozpatrywać osobno od melodii Eli, która nie tylko prezentuje odmienne opracowanie muzyczne, ale i opiera się na innych stopniach strukturalnych. Partię Chrystusa tworzą takie zwroty melodyczne,

5I Zakończenie słów ewangelisty, a zarazem przejście do partii turby.

52 Opuszczenie nuty lub całej grupy nut na początku formuły melodycznej, zob. P. Feretti, op. cit., s. 76-77.

53 Dodanie nuty lub grupy nut na początku formuły melodycznej, zob. ibid., s. 79-80.

54 Zakończenie całej pasji. 
jak initium, flexa, metrum, punctum, interrogatio i conclusio. Melodia wypowiedzi Chrystusa obejmuje szerszy zakres dźwiękowy w stosunku do partii narratora: od $c^{I}$ do $b^{I}$ (septyma mała) i mieści się w najniższym rejestrze względem pozostałych partii ze stopniem dominantowym $f^{t}$.

\section{Initium}

Podobnie jak w partii ewangelisty, zasadnicza formuła melodyczna initium ma postać wznoszącej tercji (przykł. Ioa). Nierzadko pojawia się wariant initium oparty na wypełnieniu tercji (przykł. rob).
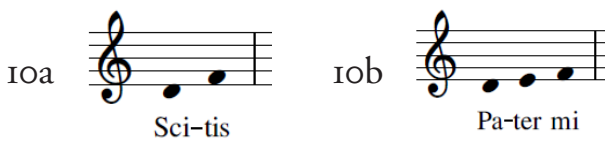

Flexa

Flexę tworzy tercja opadająca od stopnia strukturalnego $f^{I}$ (dźwięku tenorowego) (przykł. IIa). Występują warianty melodyczne tej formuły powstałe w wyniku zastosowania modyfikacji epénthesis w przypadku wyrazu proparoksytonicznego (przykł. Irb) oraz z wypełnieniem tercji (przykł. IIc), przy czym wersja melodyczna flexy z wypełnioną tercją łączy się z odmiennymi układami akcentów w tekście (np. „glaudium”, „dicite ei”). Jako odosobniony przypadek pojawia się zwrot melodyczny flexy z wypełnieniem tercji oraz dodanym dźwiękiem $d^{I}$ na przedostatniej sylabie (przykł. IId).

IIa

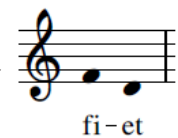

fi-et

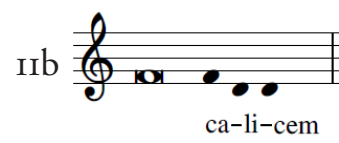

ca-li-cem

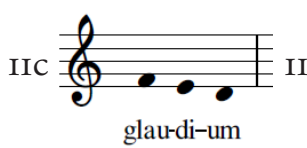

glau-di-um

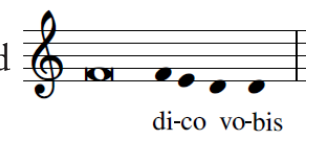

di-co vo-bis

\section{Metrum}

Metrum partii Chrystusa w rękopisie PL-Ls I4 obejmuje dwie formuły melodyczne - obie o charakterze sylabicznym - z tym że jedna z nich (metrum I) pojawia się zupełnie wyjątkowo:

$\mathrm{I} 2$

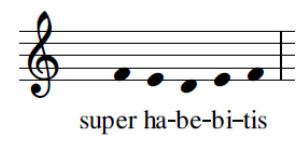

Zasadniczy zwrot melodyczny dla tego rodzaju kadencji stanowi przebieg o ogólnie descendentalnym charakterze zakończony dźwiękiem $f^{I}$ (metrum II, przykł. Iza). 
Wszystkie przypadki tej formuły występują z bemolem przy dźwięku $h^{I}$. Zwrot melodyczny metrum II w jego podstawowej formie zawsze związany jest z trzema następującymi po sobie wyrazami paroksytonicznymi (np. „amen dico vobis”, „bonum erat ei”, „dico autem vobis”, itp.). Wówczas zaś, gdy zamiast wyrazu paroksytonicznego pojawia się wyraz proparoksytoniczny, stosowana jest modyfikacja epénthesis (przykł. I3b).

I3a

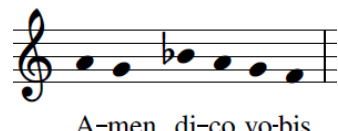

A-men di-co vo-bis

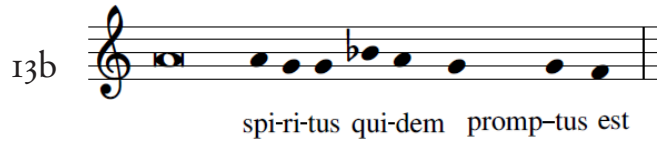

spi-ri-tus qui-dem promp-tus est

Spotykamy się z rozbieżnościami w interpretacji powyższego zwrotu melodycznego (przykł. 13a). Peter Wagner uznaje go za wzbogaconą wersję flexy5s, natomiast Włodzimierz Poźniak - za wariant conclusio ${ }^{56}$, ze względu na trzy ostatnie dźwięki wspólne w obu zwrotach (metrum i conclusio). Z kolei Antoni Reginek, wskazując na ścisły związek tejże formuły z dwukropkiem, określa ją jako metrum ${ }^{57}$. Zarówno pogląd Wagnera, jak i Poźniaka budzi duże wątpliwości, bowiem powyższy zwrot melodyczny nie ma charakteru ani flexy, ani też conclusio, ściśle związanego z zakończeniem partii Chrystusa. Niewątpliwie formuła ta ma dość szczególny charakter, łącząc się zasadniczo z podobnymi zwrotami o tym samym układzie akcentów - np. „Amen dico vobis”, „Dico autem vobis” - i nie kończy partii Chrystusa, lecz występuje jako wewnętrzny zwrot kadencyjny. Stąd, za Reginkiem, w niniejszym studium określono ten zwrot melodyczny jako metrum. Melodia odpowiadająca metrum II tożsama jest z mediantą tonus peregrinus. W sytuacji większej liczby sylab znajduje tu zastosowanie modyfikacja epénthesis $\left(a^{I}-g^{I}-b^{I}-a^{I}-g^{I}-g^{I}-f^{I}\right)$.

\section{Punctum}

Typowy zwrot melodyczny dla punctum stanowi przebieg melodyczny związany z czterema sylabami z ozdobioną trzecią sylabą od końca w postaci trzyelementowego porrectus (przykł. I4a). Jego melodia nawiązuje do terminatio z tonus peregrinus. Warianty melodyczne punctum są rezultatem takich modyfikacji jak prósthesis, syncope czy dieresis ${ }^{5}$ (przykł. I $4 \mathrm{~b}-\mathrm{d}$ ). W zasadniczym zwrocie melodycznym punctum, a także w jego licznych wariantach, akcent łączy się z przedostatnim dźwiękiem formuły.

55 Peter Wagner, Gregorianische Formenlehre, Leipzig I92I (= Einführung in die gregorianischen Melodien 3), s. 25I.

56 W. Poźniak, op. cit., s. 59.

57 A. Reginek, „Śpiewy pasji”, op. cit., s. 74 .

58 Rozdzielenie formuły melodycznej na pojedyncze dźwięki bądź mniejsze grupy, zob.: P. Feretti, op. cit., s. 87. 

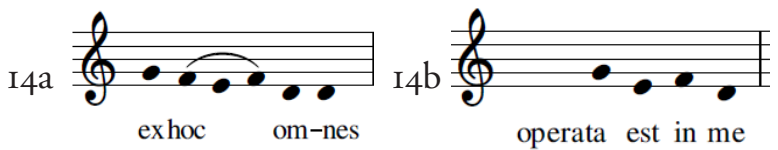

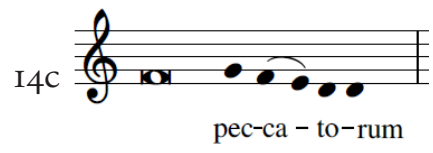

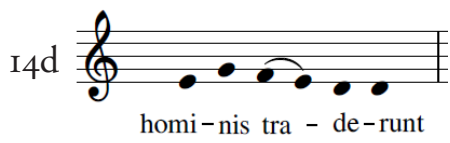

Interrogatio 59

Melodia interrogatio schodzi ze stopnia recytatywnego $\left(f^{I}\right)$ do dźwięku $c^{I}$, po czym ruchem łącznym powraca na tenże stopień strukturalny (przykł. I5). Jedyny wariant tej formuły stanowi zapis z dźwiękami stroficznymi na ostatniej sylabie. W interrogatio neuma pes występująca na przedostatniej sylabie zawsze łączy się z sylabą akcentowaną.

I5

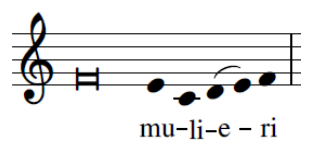

Conclusio

Partia Chrystusa obejmuje tylko jedno conclusio (przykł. I6a). Jego różne warianty melodyczne są zawsze efektem tylko jednego rodzaju modyfikacji - per suspensionem (aphéresis, syncope, apocope $e^{60}$ ) - stosowanej w przypadku krótszych tekstów (przykł. I6b-e). Przedostatni dźwięk formuły melodycznej conclusio związany jest z sylabą akcentowaną, gdy zaś na końcu pojawia się monosylaba (przykł. I6d), wówczas pojawia się modyfikacja apocope i opuszczenie ostatniego dźwięku.

I6a

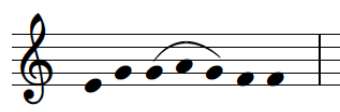

cru-ci-fi - ga-tur

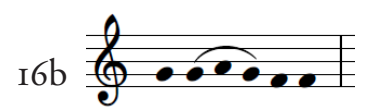

Tudi - xi-sti

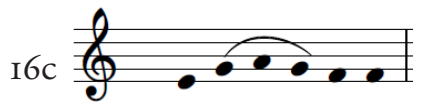

terme ne - ga-bis

I6d

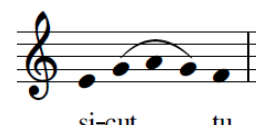

I6e

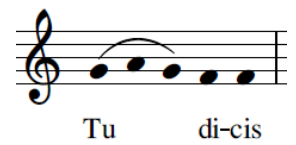

59 Formuła melodyczna występująca w zdaniu pytającym.

60 Opuszczenie dźwięku lub grupy dźwięków na końcu formuły melodycznej, zob.: P. Feretti, op. cit., s. 78. 


\section{Melodia „Eli”}

Melodia towarzysząca ostatnim słowom Jezusa przebiega w nieco wyższym rejestrze niż pozostałe fragmenty partii Chrystusa, choć cechuje się podobnym do nich ambitusem septymy małej ( $\left.e^{I}-d^{2}\right)$. Ma ona bardzo ozdobny charakter (przykł. 17). Za Poźniakiem i Reginkiem można przyjąć podział muzyczno-słowny na następujące odcinki: „Eli / Eli / lama sabachtani / Hoc est / Deus meus / Deus meus / ut quid dereliquisti me".

I7

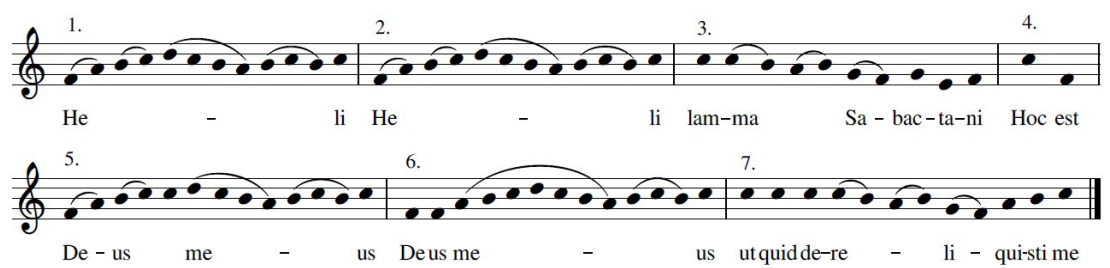

Trzy ostatnie odcinki (z tekstem łacińskim) zasadniczo odpowiadają pod względem melodycznym trzem pierwszym odcinkom. Występują pomiędzy nimi jedynie drobne różnice będące wynikiem modyfikacji adaptacyjnych; różnią się ponadto zwrotami kadencyjnymi: trzy ostatnie sylaby trzeciego odcinka otrzymały dźwięki $g^{I}-e^{I}-f^{I}$, zaś siódmego $-a^{I}-h^{I}-c^{2}$. Łącznikiem tych dwóch części melodii (odcinki I-3 i 5-7), a zarazem osią wyznaczającą podział na te części, jest odcinek czwarty stanowiący formułę punctum partii ewangelisty z zastosowaniem modyfikacji syncope (skok kwinty w dół: $c^{2}-f^{\prime}$ ) ze względu na krótszy tekst („Hoc est”).

Melodia związana z pierwszym wyrazem „Eli” (odcinek I) jest powtórzona bez żadnych zmian przy powtórnym wołaniu Chrystusa (odcinek 2), natomiast w adaptacji tego wzorca melicznego do tekstu łacińskiego (odcinki 5 i 6) występują zmiany dotyczące w pierwszym rzędzie powtórzonego „Deus meus” (odcinek 6), które są wynikiem zastosowania modyfikacji prósthesis oraz odmiennego ugrupowania neumatycznego. Strukturę całej wypowiedzi muzycznej fragmentu „Eli”, biorąc pod uwage wykorzystanie określonych struktur melodycznych, w sposób schematyczny można przedstawić następująco:

\begin{tabular}{|c|c|c|c|c|c|c|}
\hline A & A & B & C & A' $^{\prime}$ & A" $^{\prime \prime}$ & B' $^{\prime}$ \\
\hline odcinek 1 & odcinek 2 & odcinek 3 & odcinek 4 & odcinek 5 & odcinek 6 & odcinek 7 \\
\hline
\end{tabular}

PARTIA TURBY

Partia turby obejmuje dwa stopnie recytacyjne $-d^{2}$ oraz $f^{2}$. Melodia mieści się w obrębie kwarty - jest to najwęższy ambitus wśród trzech partii pasyjnych. Nie 
wykracza poza dźwięk tenorowy $f^{2}$ na górze, na dole zaś zstępuje jedynie o jeden ton poniżej stopnia recytatywnego $d^{2}$.

\section{Initium}

Typowe initium dla turby, jak i dla pozostałych partii, stanowi wznosząca się tercja mała (przykł. I8a). Wówczas jednak, gdy tenor występuje na dźwięku $d^{2}$, jest ono pomijane, poza jedynym przypadkiem, w którym po formule punctum initium rozpoczyna się dźwiękiem $h^{I}$ i wprowadza stopień tenorowy $d^{2}$ (przykł. I8b).
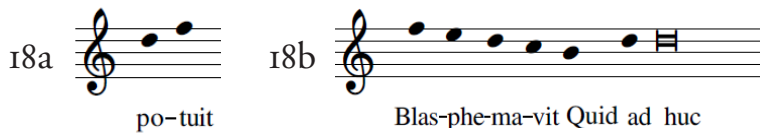

Flexa

Ten rodzaj typowej formuły, charakteryzujący się opadającą tercją małą dla całej melodii pasyjnej, pomimo zastosowania w melodii turby dwóch stopni recytatywnych $\left(f^{2}\right.$ i $\left.d^{2}\right)$, występuje tylko po tenorze $f^{2}$ (przykł. I9a). Jeden z wariantów melodycznych flexy stanowi jej rozszerzenie poprzez zastosowanie modyfikacji epénthesis dla wyrazów proparoksytonicznych (przykł. I9b), inny zaś - poprzez wypełnienie tercji (przykł. I9c).

I9a

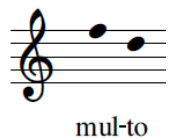

I9b

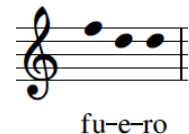

I9C

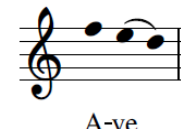

\section{Metrum}

Struktura meliczna metrum różni się w zależności od stopnia tenorowego, po którym następuje: po dominancie $f^{2}$ melodia tworzy łukowy kształt do dołu (przykł. 20a) - odpowiadając tym samym metrum I partii Chrystusa (które jest położone o oktawę niżej ze względu na rejestr partii), z kolei po recytatywie na dźwięku $d^{2}$ melodia układa się łukowo do góry (przykł. 2of). Mamy zatem w partii turby dwa rodzaje metrum związane z własnymi stopniami recytatywnymi. Warianty melodyczne metrum I powstają w wyniku zastosowania takich modyfikacji jak epénthesis, syneresis ${ }^{6 \mathrm{I}}$ (przykł. 2ob-d) oraz jednokrotnie poprzez per mutationem ${ }^{62}$,

6I Ten rodzaj modyfikacji zachodzi wówczas, gdy nuty, które pierwotnie były związane z kilkoma sylabami, łączą się w jedną grupę na jednej sylabie, zob.: P. Feretti, op. cit., s. 85 .

62 Zastąpienie jednej nuty inną, zob. ibid., s. 88. 
z zastąpieniem ostatniego dźwięku $f^{2}$ nutą niższą - $e^{2}$ (przykł. 2oe). Metrum II występuje głównie w formie zasadniczej (przykł. 2of), tylko w jednym miejscu spotykamy zastosowanie modyfikacji per mutationem, gdzie melodia po osiagnięciu najwyższego punktu nie powraca na stopień $d^{2}$, lecz schodzi tylko o sekundę na $e^{2}$ (przykł. 20g).

$20 \mathrm{a}$

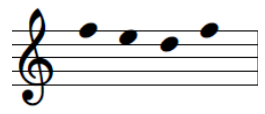

in cor-bo-nam

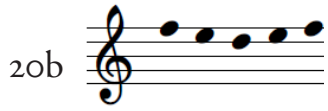

fu-e-rintin te
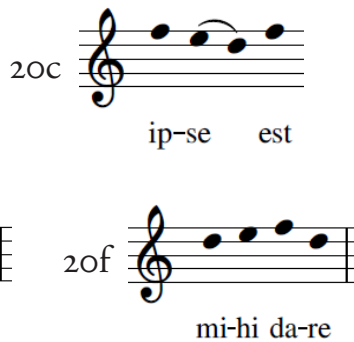

mi-hi da-re

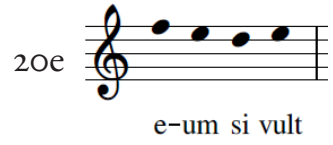

e-um si vult
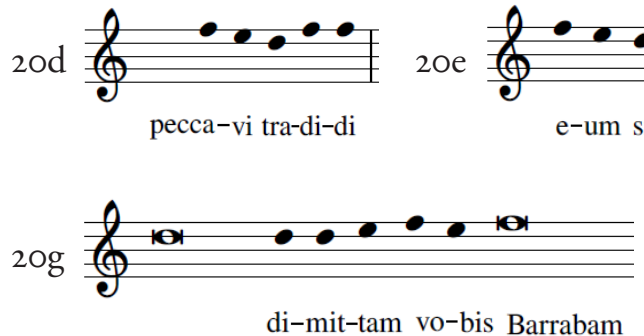

Formuła zasadnicza metrum I łączy się z różnymi układami akcentów w tekście (np. „ejus super nos”, „in corbonam”), stąd trudno określić powód zastosowania tak licznych i różnorodnych modyfikacji. Być może chodzi o zwykłe wzbogacenie melodii partii turby. Z kolei w przypadku drugiego metrum (przykł. 2of) najwyższy dźwięk zawsze jest związany z przedostatnią sylabą akcentowaną.

\section{Punctum}

Typowy zwrot melodyczny punctum stanowi melodia o descendentalnym charakterze przechodząca od stopnia recytatywnego $\left(f^{2}\right)$ do dźwięku $c^{2}$ (przykł. 2Ia). Przedostatni dźwięk tej formuły związany jest z sylabą akcentowaną. Punctum obfituje w liczne warianty, wynikające z różnorodnych modyfikacji. Można obserwować tu zarówno dodanie dźwięku, jak i opuszczenie (epénthesis, epithesis i syncope), ściągnięcie sąsiadujących nut w neumę clivis (syneresis), a także zastąpienie jednego dźwięku innym (per mutationem). Ściągnięcie dźwięków w jedną grupę czy ich opuszczenie najczęściej wiąże się z adaptacją formuły do krótszego tekstu, zaś dodanie - do dłuższego. Jednak nawet przy tej samej liczbie sylab i układzie akcentów stosowane są tu odmienne zabiegi modyfikacyjne wzbogacające i urozmaicające strukturę meliczną kompozycji (np. przykł. 2Ie, 2If, 2rh). Podobnie jak i w wielu innych formułach typowych zdarza się znak bivirgi na ostatniej sylabie. 

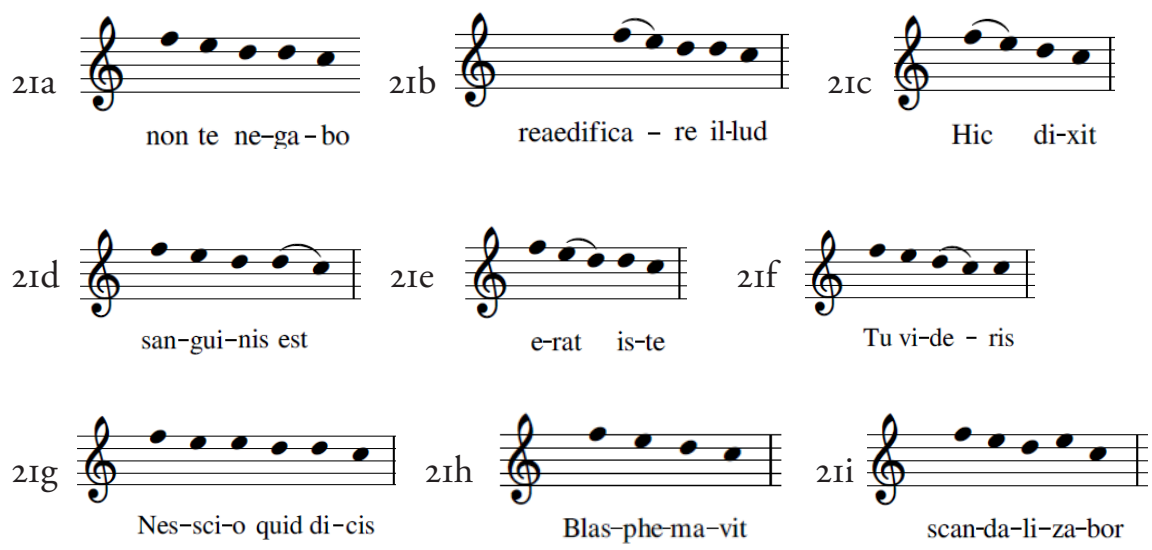

\section{Interrogatio}

W zależności od dźwięku recytatywnego $-f^{2}$ lub $d^{2}$ - zwrot melodyczny interrogatio może wystąpić w dwóch nieco odmiennych postaciach melodycznych: w pierwszym przypadku melodia zaczyna się od dźwięku recytacyjnego $f^{2}$ (przykł. 22a), w drugim zaś - z dominantą $d^{2}-$ od dźwięku $e^{2}$ (przykł. 22b). W obu przypadkach melodia, sięgnąwszy najniższej nuty zwrotu melodycznego $\left(c^{2}\right)$, zmienia kierunek i podąża krokiem sekundowym na stopień strukturalny $f^{2}$.

$22 \mathrm{a}$

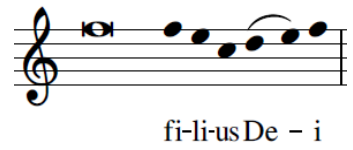

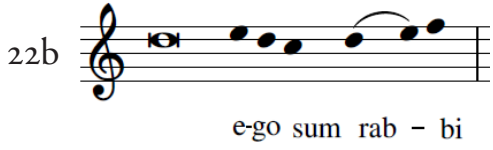

W obu zwrotach melodycznych interrogatio (interrogatio I i II) pierwszy dźwięk formuły i pes na sylabie przedostatniej łączą się z sylabami akcentowanymi. Kiedy zaś pierwszy wyraz jest paroksytoniczny, wówczas stosowana jest modyfikacja aphéresis poprzez opuszczenie dźwięku $e^{2} \mathrm{w}$ interrogatio I bądź $d^{2} \mathrm{w}$ interrogatio II (są to dźwięki związane ze środkową sylabą wyrazu proparoksytonicznego w zasadniczej formie interrogatio). Poza tym występują warianty melodyczne powstałe po zastosowaniu modyfikacji syneresis ze względu na monosylabę na końcu formuły oraz modyfikacji dieresis dla wyrazu proparoksytonicznego (również w zakończeniu formuły).

Melodia pasji w rękopisie PL-Ls I4 bogata jest nie tylko w liczne formuły typowe, ale i ich rozmaite warianty melodyczne powstałe w wyniku zastosowania modyfikacji powszechnie używanych przy adaptacjach melodii wzorcowych. Istotna część modyfikacji w oczywisty sposób wynika z odmiennej długości tekstu, z którym dana 
formuła typowa jest związana (por. przykł. i6a i i6e) lub też układu akcentów (np. zastosowanie modyfikacji epénthesis dla flexy w przypadku wyrazu proparoksytonicznego). Nie zawsze jednak użycie którejś z modyfikacji w formułach typowych podyktowane jest odmienną liczbą sylab czy też układem akcentów, zdarzają się także przypadki, w których można obserwować wprowadzenie modyfikacji melodycznej bez tego rodzaju uzasadnienia, jako środek muzycznego urozmaicenia.

$\mathrm{Z}$ zastosowania w pasjach zawartych w źródłach polskich ${ }^{63}$ tego samego wzorca modalnego (tonu F) wynika także podobieństwo formuł typowych ${ }^{64}$. Niemniej każda kompozycja ma cechy indywidualne, przejawiające się nie tylko w zróżnicowanym doborze środków adaptacyjnych melodii, ale i w zastosowaniu struktur melicznych charakterystycznych dla danego utworu. Swoiste cechy ma także pasja z kodeksu PL-Ls I4. Istotnie odmienny element w stosunku do pozostałych kompozycji stanowi tu formuła terminatio (przykł. 9) o dość rozbudowanej formie, która nie ma dokładnego odpowiednika w żadnym innym rodzimym źródle. W przypadku wypowiedzi narratora interesująca jest także formuła conclusio przed partią Chrystusa (przykł. 7), która jedynie w PL-Kp 1706 ma identyczną postać jak w PL-Ls I4 - z trzyelementowym climacus od dźwięku $c^{2}$ na trzeciej sylabie od końca - podczas gdy we wszystkich kodeksach wawelskich i dwóch starszych księgach bernardyńskich występuje czteroelementowa neuma climacus od dźwięku $d^{2}$ (w trzecim - najmłodszym - kancjonale bernardyńskim PL-Kc I613 ten zwrot melodyczny jest bardziej rozbudowany). Ta drobna różnica jest interesująca z tego względu, iż dźwięk $d^{2}$ został dodany w okresie późniejszym także w kompozycji z księgi kraśnickiej. Tego typu poprawki świadczą z jednej strony o praktyce śpiewu pasji zapisanej w kodeksie PL-Ls I4, z drugiej zaś o dostosowywaniu się do różnych tradycji wykonawczych, w tym przypadku najprawdopodobniej związanych z katedrą wawelską (tym bardziej, że kanonicy regularni stosowali liturgię diecezjalną). Jeśli chodzi o pozostałe formuły typowe dla partii ewangelisty - initium, flexa, metrum, punctum, conclusio przed partią turby - poza drobną różnicą w punctum $\mathrm{w}$ księgach bernardyńskich, w których zamiast pojedynczego dźwięku na przedostatniej sylabie $\left(a^{I}\right)$ występuje neuma clivis $a^{I}-g^{I}$ (w kodeksie PL-Kc 36r3 ponadto nie używa się formuły initium $\mathrm{w}$ żadnej z partii), te same zwroty melodyczne stosowane w pasji z PL-Ls I4 występują we wszystkich pozostałych kom-

63 Pasję z kodeksu PL-Ls I4 porównano ze znanymi dotychczas kompozycjami zawartymi w źródłach polskich: PL-Kk 58, Cantionale cum Agenda, I489 r.; PL-Kk 59, Cantionale, I430-40, z katedry na Wawelu (olim 90); PL-Kk 235, Cantionale, 3. ćw. XV w., z katedry na Wawelu; PL-Kk 240, Cantionale Cracoviense, I447-56, z Wieliczki (?); PL-Kp 1706, Cantionale Wawrzyńca Gieskiego, I496 r.; PL-Kc 3606, Cantionale, XVI w., z klasztoru bernardynów krakowskich (?); PL-Kc 3607, Cantionale, XVI w. (fragm.), z klasztoru bernardynów krakowskich (?); PL-Kc 36I3, Cantionale, XVI/XVII w., z klasztoru bernardynów krakowskich (?). Nieznane dotąd pasje z rękopisów PL-WRzno 3070/II oraz PL-WŁs 720 także zostały skomponowane w tonie F, zostaną one bliżej przedstawione w zbiorczej pracy o pasjach chorałowych w Polsce.

64 Zestawiono ze sobą melodie pasji według św. Mateusza. 
pozycjach z wymienionych źródeł. A zatem, w kontekście partii narratora melodia pasji z rękopisu PL-Ls I4 wykazuje silniejszy związek z kompozycjami wawelskimi, aniżeli bernardyńskimi. Z kolei zaś w kontekście partii Chrystusa drobne różnice w niektórych zwrotach melodycznych pasji „kraśnickiej” w stosunku do melodii „bernardyńskich” dotyczą także niemal wszystkich pasji wawelskich (we wszystkich pasjach krakowskich występuje neuma pes zamiast pojedynczego dźwięku w metrum oraz rozszerzone o jeden dźwięk punctum); tylko w kompozycji z PL-Kk 59 wszystkie formuły typowe są tożsame z „kraśnickimi”. Jeśli chodzi o strukturę meliczną ostatnich słów Chrystusa w PL-Ls I4 (przykł. 17), nie ma ona w całości dokładnego odpowiednika w żadnej innej kompozycji, choć wszystkie te melodie stanowią warianty jednego wzorca melicznego. W dość szczególny sposób w kodeksie kraśnickim jest ukształtowana partia turby, bowiem ze względu na zastosowanie dwóch stopni recytatywnych występują dwa nieco różniące się od siebie zwroty melodyczne formuły interrogatio (interrogatio I i II) oraz metrum (metrum I i II). Poza tym, można by mówić o wyjątkowym podobieństwie formuł typowych turby pasji „kraśnickiej” z melodiami w źródłach zarówno wawelskich, jak i bernardyńskich (poza PL-Kc 36r3 w którym występuje nieco odmienne ukształtowanie melodyczne formuł punctum i interrogatio I).

Badania porównawcze melodii pasji z kodeksu kraśnickiego i pozostałych melodii pochodzących z ksiąg o rodzimej proweniencji pokazują, iż kompozycja ta harmonijnie wpisuje się w znany już polski repertuar pasji chorałowej ${ }^{65}$. Pomimo jednak wyraźnego podobieństwa struktury melicznej kompozycji zawartych w źródłach polskich, opartych na tym samym szkielecie modalnym $f^{I}-c^{2}-f^{2}$, wszystkie opracowania muzyczne tego gatunku odznaczają się swoistymi cechami wynikającymi z różnorodnego wyboru środków adaptacyjnych. Jako najbardziej pokrewne omawianej pasji pod względem struktury melicznej wymienić należy pasje z kancjonału sporządzonego przez Wawrzyńca z Giesek w 1. I496-97 w Krakowie dla potrzeb opatowskiej kolegiaty św. Marcina (PL-Kp I706) ${ }^{66}$, a także z najstarszego w tej grupie rękopisu wawelskiego PL-Kk 59. Najdalej z kolei od PL-Ls I4 odbiega pod względem kształtowania melodii najmłodszy z rękopisów bernardyńskich (PL-Kc 3613 $)^{67}$, który w stosunku do wszystkich omawianych kompozycji charakte-

65 Szersze badania porównawcze - obejmujące także inne źródła środkowo- i zachodnioeuropejskie (w tym też księgi śląskie) - będą prowadzone w ramach zamierzonego opracowania poświęconego pasji chorałowej w źródłach polskich. W dotychczasowych opracowaniach jako źródła polskie cytowano także trzy rękopisy śląskie - PL-WRk 58, PL-WRk I78, PL-WRu I Q 225, z kolei pomijany był ewangelistarz głogowski (PL-WRu I F 459) z I348 roku. Księgi śląskie - te znane, jak i te nie cytowane w dotychczasowej literaturze przedmiotu - zostaną uwzględnione w planowanym studium.

66 K. Morawska, op. cit., s. I03, 236, 320.

67 Dwie pozostałe pasje z ksiąg bernardyńskich (PL-Kc 3606, PL-Kc 3607) wykazują dość silne podobieństwo zarówno z kompozycją z PL-Ls I4, jak i innymi pasjami zawartymi we wspomnianych księgach polskich związanych z ośrodkami diecezjalnymi. 
ryzuje się nieco innym i bardziej ozdobnym ukształtowaniem melodycznym niektórych formuł typowych. Większe urozmaicenie melodyczne tej pasji może wiązać się ze stosunkowo późnym pochodzeniem rękopisu - datowany jest on bowiem na przełom XVI i XVII wieku.

Chociaż każda z pasji wyróżnia się bogactwem wariantów melicznych poszczególnych formuł typowych, szczególnie interesująca pod tym względem jest prezentowana kompozycja z PL-Ls I4, którą ponadto wyróżnia unikatowy zwrot melodyczny terminatio (przykł. 9) oraz zastosowanie dwóch stopni recytacyjnych dla partii turby $\left(f^{2}\right.$ i $\left.d^{2}\right)$, co jest coraz rzadziej spotykane w pasjach późniejszych ${ }^{68}$.

\section{PLAINCHANT PASSION FROM THE SERMON COLLECTION OF THE CANONS REGULAR OF THE LATERAN IN KRAŚNIK}

Studies on the plainchant Passion settings in Poland were inaugurated by Włodzimierz Poźniak (in 1947) and continued by Father Antoni Reginek. In recent years, the list of such compositions has been extended thanks to further library surveys and research into Polish medieval sources of liturgical music. The present paper presents a previously unknown composition from a manuscript kept at the Library of the Metropolitan Seminary in Lublin (shelf mark Rkps I4; siglum PL-Ls I4; old shelf marks 235, B I3, B 17), which appears to be the oldest music work of this kind found in a Polish source (dated to I4II), most likely from the Lesser Poland region, like all the other sources of Polish plainchant Passions known to date. The codex is not a book of sheet music, but a collection of sermons. The St Matthew Passion (fol. I65r-172v) is the only music composition found in this source. According to a I7th-century note found on the first folio of this manuscript (PL-Ls I4, fol. Ir), the book belonged to the Canons Regular of the Lateran in Kraśnik.

The Passion melody found in PL-Ls I4 is based on the F tone - applied exclusively in Passions found in Polish sources. The composition abounds in typical formulas, but also in their melodic variants derived from modifications commonly introduced to adapt the model melodies. A large proportion of the modifications clearly result from the varying length of the text with which the typical formula is associated, or from the pattern of accents. However, the use of a given modification in a typical formula is not always determined by the changing number of syllables or by the arrangement of accents. In some cases, melodic modifications are introduced without such a justification, rather as a means of diversifying the musical setting. Comparative studies of the Passion melodies from the Kraśnik codex and from the other sources of Polish provenance prove that the Kraśnik Passion matches very well the previously known plainchant Passion repertoire from this area. Despite the evident similarity of

68 Dwa stopnie recytatywne sporadycznie występują w PL-Kk 59 (I430-40), zupełnie wyjątkowo w PL-Kk 58 (I489). 
melodic structures in works found in the Polish sources, which are based on the same modal framework $\left(f^{1}-c^{2}-f^{2}\right)$, each of the settings has its own individual qualities as well, resulting from the way this framework was adopted in the given work.

Translated by Tomasz Zymer

Słowa kluczowe / keywords: pasja chorałowa / plainchant Passion, ton pasyjny / Passion tone, ton pasyjny F / F Passion tone, kancjonał (cantionale) / hymnbook (cantionale)

Dr Irina Chachulska, adiunkt w Zakładzie Muzykologii Instytutu Sztuki PAN. Prowadzi także zajęcia z chorału gregoriańskiego na II Wydziale UMFC. Ukończyła Instytut Muzykologii KUL oraz kierunek Muzyka Kościelna na UMFC. Zajmuje się problematyką chorałową z zakresu semiologii, estetyki i modalności gregoriańskiej. Aktualnie prowadzi badania skoncentrowane wokół polskich średniowiecznych źródeł chorałowych. Jest członkiem zespołów badawczych Plainchant Sources in Poland - Cantus Planus in Polonia oraz Manuscripta.pl - A guide to medieval manuscript books in Polish collections. irina.chachulska@ispan.pl

\title{
Publikacja projektu HERA „Sound Memories”
}

The polyphonic hymns of Valentin Triller's

Ein Schlesich singebüchlein (Wrocław 1555)

edited by Antonio Chemotti

zamówienia:iswydawnictwo@ispan.pl

www.soundme.eu

\section{Archiwalne zeszyty „Muzyki”}

\author{
www.ispan.pl/pl/wydawnictwa/ czasopisma \\ iswydawnictwo@ispan.pl
}


